\title{
Mehmet Tekin, Tarık Buğra: İtaatsiz, Bir Taşralının Entelektüiel Portresi, Ötüken Yayınları, İstanbul 2018, 686 s., ISBN: 978-605-155-716-8 (Tanıtma)
}

İmren Gece Özbey ${ }^{1 \odot}$

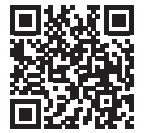

${ }^{1}$ Arş. Gör., Istanbul Üniversitesi, Edebiyat Fakültesi, Türk Dili ve Edebiyatı Bölümü, Istanbul, Türkiye

Sorumlu yazar/Corresponding author: İmren Gece Özbey,

Istanbul Üniversitesi, Edebiyat Fakültesi,

Türk Dili ve Edebiyatı Bölümü, İstanbul, Türkiye

E-mail: imren.gece@istanbul.edu.tr,

imrengece@gmail.com

Geliş tarihi/Date of receipt: 06.11 .2018

Kabul tarihi/Date of acceptance: 19.11.2018

\section{Atıf/Citation:}

Gece-Özbey, I. (2018). İtaatsiz Bir Taşralının Entelektüel Portresi [M. Tekin ve T. Buğra

tarafindan yayına hazırlanan itaatsiz Bir

Taşralının Entelektüel Portresi başlıklı kitabın

değerlendirmesi]. TUDED 58(2), 449-451.

https://doi.org/10.26650/TUDED486783

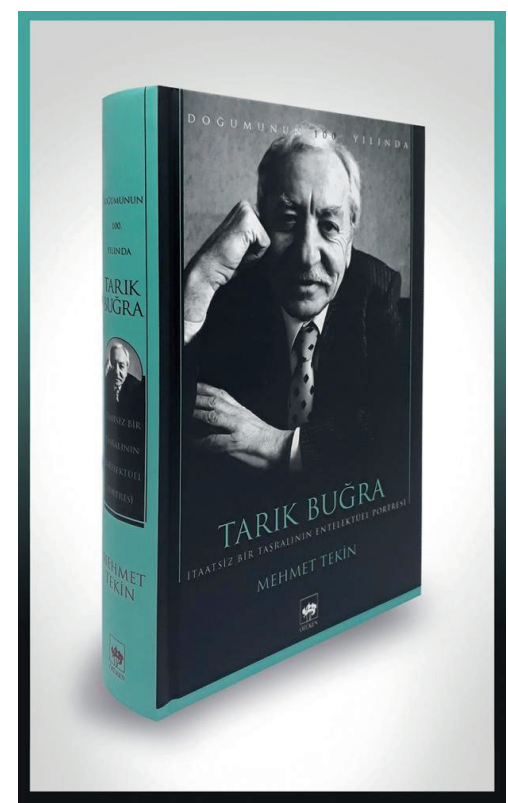


Edebiyat araştırmalarında yazarın yetiştiği ortamı, kimliği ve kişiliğini, yaşamının eserlerine etkisini ve yaşadığı devrin yazar üzerindeki yansımalarını tahlil edebilmek yazar merkezli araştırmalar açısından büyük öneme sahiptir. Bu bağlamda, bir yazarın yaşam öyküsünü her yönüyle ele alan biyografik çalışmaların edebiyat araştırmacısı için ne denli önemli olduğu yadsınamaz. Bilhassa, yazarın yaşam öyküsüyle yetinmeyerek onu yaşadığı zaman ve mekânın bütün cihetleriyle beraber değerlendirebilen kuşatıcı çalışmaların kıymeti büyüktür.

Mehmet Tekin'in Türk Edebiyatının en önemli kalemlerinden biri olan Tarık Buğra hakkında bu güne dek yapılmış en kapsamlı biyografik çalışma olan Tarık Buğra: Itaatsiz Bir Taşralının Entelektüel Portresi adlı eseri, büyük yazarın doğumunun yüzüncü yılında okuyucuyla buluşmuştur. Mehmet Tekin, üzerinde uzun yıllar çalışmış olduğu eseri "Bu kitap (...) bir biyografi, yani hayatı hedefleyen, dolayısıyla ünlenip belleklerde ve kitaplarda yer almış birinin hayatını anlatan bir çalışma. Ancak hayatı, kronoloji mantığıyla anlatan -tabiri caizse- bir silsilenâme değil; bir hikâye, daha doğrusu öyle adlandırılmasını beklediğim bir metinler manzumesi." olarak tanımlar.

Çalışma, "İtaatsiz Bir Taşralının Ön Portresi”, “Imparatorluk'ta Doğmak Cumhuriyet'te Büyümek”, "Inkılap Yıllarının Gölgesinde”, "Üniversitede Fakülteler Okumak”, “Demokrasi Çağında Gazeteci Olmak", "Ev ve Evlilikler" ve "Sanatçının Ölümü" başlıklarını taşıyan yedi bölüm ile çalışmayı tamamlayıcı evrak, yazı ve fotoğraflardan oluşan "Ek Bölüm"den oluşmaktadır.

"Itaatsiz Bir Taşralının Ön Portresi" başlıklı birinci bölümde, Tarık Buğra'nın yaşam öyküsü, söyleşileri ve eserlerinden yola çıkılarak mizacı, felsefesi ve dünya görüşü bağlamında yazarın portresi çizilmeye çalışılmaktadır.

“Imparatorluk'ta Doğmak Cumhuriyet'te Büyümek" başlıklı ikinci bölümde mekân ve aile faktörleri merkeze alınarak "Akşehir" ve "Evin Sahipleri" alt başlıkları altında yazarın kişiliğinin temelini oluşturan, doğduğu ve büyüdüğü fiziki ve sosyal çevrenin bir çerçevesi çizilmiştir.

Üçüncü bölüm "İnkılap Yıllarının Gölgesinde” başlığını taşır ve bu bölümde Tarık Buğra'nın yaşamının ilkokul yıllarından üniversiteye girişine kadarki dönemi (1918-1925) devrin sosyali ekonomik ve siyasi şartları içerisinde ele alınmaktadır. Bölümde, bu yıllarda hayatına giren insanların ve bazı tecrübelerin yazarın edebiyata yönelmesindeki etkisini izlemek mümkündür.

"Üniversitede Fakülteler Okumak" başlığını taşıyan dördüncü bölümde, yazarın önce Tıp ve Hukuk, askerliğin ardından ise Edebiyat Fakültesi'ne kaydoluşu, fakülte yılları, bu fakülteleri bırakmasının ardında yatan sebepler ve en önemlisi de Buğra'nın, Küllük Kahvesi müdavimliğinden başlayarak edebiyat çevrelerine girişi üzerinde durulmuştur. 1936-1950 yılları arasını konu alan bölümde ayrıca, Buğra'nın ilk hikâye tecrübesi, ilk aldığı 
ödül, Oğlumuz kitabının yayımlanması, Ahmet Hamdi Tanpınar ve Mehmet Kaplan'la kurduğu münasebet, Edebiyat Fakültesi'nden ayrılışı bahisleri de yer almaktadır.

Beşinci bölüm "Demokrasi Çağında Gazeteci Olmak" üst başlığıyla Tarık Buğra'nın "benim hamallığım oldu" dediği gazetecilik serüvenine ayrılır. Yazarın Nasrettin Hoca, Milliyet, Yeni Gün, Vatan, Tercüman, Yeni İstanbul, Yol, Türkiye Spor, Türkiye gazetelerinde çalıştığı Babıâli yılları, devrin siyasi hadiseleri ve bu hadiselerin medyaya- medyanın da hadiselere- olan etkileri yazarın yaşam öyküsü etrafında adeta bu yılların bir panoraması şeklinde sunulmaktadır. Bu bölümde uzun yıllar köşe yazarlığı da yapmış olan Buğra'nın siyasi duruşu ve ülkede meydana gelen siyasi değişimler-hadiseler karşısındaki fikirleri yazdığı yazıların ışığında ortaya konulmaktadır. Devrin olayları ve ideolojik çalkantılar içinde geçen uzun gazetecilik yıllarında yazma faaliyetini de devam ettiren Buğra'nın yazarlık serüveni de bu bölümün başlıca meselelerinden biridir.

"Ev ve Evlilikler" başlıklı altıncı bölüm ve "Sanatçının Ölümü" başlıklı yedinci bölümde Tarık Buğra'nın özel yaşamının ayrıntıları ile hastalık süreci ve vefatı anlatılmaktadır. Söz konusu bölümler, Tarık Buğra'nın eşi Hatice Bilen Buğra'nın tanıklığıyla beslenmekte; önceki bölümlerde olduğu gibi gazete küpürleri, fotoğraf ve çeşitli evrakla da desteklenmektedir.

Eserin sonunda bir de "Ek Bölüm" bulunmaktadır. Bu bölümde "Kekik Kokusu", "Bekâr", "Oğlumuz", "Yusuf Ziya Ortaç'ın Mektubu", "Turgut Evren'le Yapılan Sözleşme", "Metin Toker'in Mektubu”, "Askerlik Belgesi”, "Zeytin Dalı,, "Tarık Buğra'nın Bir Şiiri”, “Tarık Buğra'nın Heykeli" başlıklı yazı, şahsi evrak, mektup ve fotoğraflar yer almaktadır.

Tarık Buğra, Türkiye'nin yetiştirdiği, devrinin tanıklığını estetikten ödün vermeden yapmayı başarabilmiş önemli bir edebiyatçıdır ve onun hayatını tüm yönleriyle devrin sosyal ve siyasi atmosferi ile harmanlamayı başarabilmiş olan bu çalışma alanında önemli bir eksikliğe cevap vermektedir. Eserle birlikte Mehmet Tekin'in ona büyük ölçüde kaynaklık etmiş olan ve yazarla yapılmış otuz dört adet mülakatı ihtiva eden Edebiyatın Yolları Taştan: Tarık Buğra ile Söyleşiler adlı çalışması da Ötüken Yayınları'ndan çıkan yeni baskısıyla okuyucuya tekrar ulaşma imkânı bulmuştur. ${ }^{1}$

1 Mehmet Tekin, Edebiyatın Yolları Taştan: Tarık Buğra İle Söyleşiler, Ötüken Yayınları, İstanbul 2018, 340 s. 
